\title{
Pathogenesis-related proteins in Brazilian wheat genotypes: Protein induction and partial gene sequencing
}

\author{
Proteínas relacionadas à patogênese em genótipos brasileiros de \\ trigo: Indução e seqüenciamento parcial
}

\section{Loreta Brandão de Freitas $^{1}$ Patrícia Koehler-Santos ${ }^{2}$ Francisco Mauro Salzano ${ }^{3}$}

\section{ABSTRACT}

Leaves from 14 Brazilian genotypes of Triticum aestivum L. were treated with salicylic acid to induce pathogenesis-related $(P R)$ proteins. Inter and intracellular extracts were then obtained and investigated through polyacrilamide gel electrophoresis. Seven bands were observed. Material related to two of them (of 40 and $24 \mathrm{kDa}$ ) occurred in intracellular spaces only. DNA from these same genotypes was then amplified through PCR using primers developed from three sequences encoding $P R$ proteins, and compared with previously described sequences. The fragments presented homologies to PR groups 1, 3 (chitinases), and 5 (thaumatinlike). The PR3-like sequence also showed a site characteristic of PRs induced by ethylene and a portion without homology with previous sequences. No variation among genotypes were observed, either for protein extracts or DNA sequences.

Key words: Triticum aestivum $L_{\text {., }}$ defense proteins, genetic variability.

\section{RESUMO}

Folhas de 14 genótipos brasileiros de Triticum aestivum L. foram tratadas com ácido salicílico para a indução de proteinas relacionadas à patogênese (PR). Extratos inter e intracelulares foram assim obtidos e estudados através de eletroforese em gel de poliacrilamida. Sete bandas foram observadas, sendo que o material referente a duas delas (de 40 e $24 \mathrm{kDa}$ ) foi detectado somente nos espaços intracelulares. O DNA desses mesmos genótipos foi então amplificado através de PCR, usando iniciadores desenvolvidos a partir de três seqüencias que codificam proteínas $P R$, e comparados com seqüencias previamente descritas. Eles apresentaram homologia com os grupos PR 1, PR 3 (quitinases) e PR 5 (semelhante à taumatina), sendo que a seqüência do grupo $P R 3$ apresentou também um sitio característico de PRs induzidas pelo etileno e uma porção sem homologia com seqüencias prévias. Não foi observada qualquer variação entre genótipos, seja nos extratos protéicos ou nas seqüencias de DNA.

Palavras-chave: Triticum aestivum L., proteinas de defesa, variabilidade genética.

\section{INTRODUCTION}

Plants react to pathogen attack by activating an elaborate defense mechanism that acts both locally and systemically. In many cases, local resistance is manifested as a hypersensitive response, which is characterized by the development of lesions that restrict pathogen growth and/or spread (DIXON \& HARRISON, 1992). Associated with the hypersensitive response is the induction of a diverse group of defenserelated genes and several families of pathogenesisrelated proteins (PR) (DURNER et al., 1997). Induction of PR proteins is usually accompanied by the development of local and/or systemic resistance to subsequent infection by several related or unrelated

\footnotetext{
${ }^{1}$ Biologist, PhD., Associate Professor, Departamento de Genética, Instituto de Biociências (IB), Universidade Federal do Rio Grande do Sul (UFRGS), CP 15053, 91501-970, Porto Alegre, RS. E-mail: loreta.freitas@ufrgs.br. Corresponding author ${ }^{2}$ Biologist, MSc, Departamento de Genética, IB, UFRGS.

${ }^{3}$ Biologist, PhD., Departamento de Genética, IB, UFRGS.
} 
pathogens (VAN LOON, 1985; BOL et al., 1990; LINTHORST, 1991). Common characteristics of PR proteins are selective extractability at low $\mathrm{pH}$; high resistance to proteases; localization in intercellular spaces; salicylic acid (SA) induction; and low molecular weight (VAN LOON, 1985; TAMÁS \& HUTTOVÁ, 1996). PR proteins occur in a wide variety of plant species (about 79 species belonging to 16 taxonomic families, including mono and dicotyledons), suggesting they play an important role in the resistance reaction of plants (MOHAMED \& SEHGAL, 1997).

The objectives of the present work were: a) to identify PR proteins induced by salicylic acid in wheat; b) study the genetic regions responsible for these types of proteins; and c) verify eventual differences among genotypes in relation to them.

\section{MATERIAL AND METHODS}

Wheat (Triticum aestivum L.) seedlings of 14 Brazilian genotypes (PF8914; PF9027; PF89119; PF89339; PF889199; PF889300; BR23; BR32; BR35; BR43; IAC13; TOROPI; PF844002; PF844007) were placed in a growth chamber at $20^{\circ} \mathrm{C}$ and submitted to a photoperiod of 12 hours. Seven-day-old seedlings were then transferred to a greenhouse, and plants with eight leaves were sprayed three times with $5 \mathrm{mM}$ salicylic acid (SA), at 24 hour intervals. Twenty-four hours after the last spray, the leaves were washed with distilled water to remove excess of salicylic acid, and the proteins were immediately extracted. Control plants were submitted to the same procedure, using distilled water instead of SA.

Extraction of the intercellular PR fraction was performed by vacuum infiltration of citrate-phosphate buffer, $\mathrm{pH} 2.9$ through the plant vessels in two periods of ten minutes. Afterwards, leaves were transferred to plastic syringes with a layer of filter paper at the bottom. This material was then centrifuged (20 minutes at 1,500 $\mathrm{g}$ ), and the intercellular washing fluid (IWF) was collected for study.

To obtain the intracellular PR material, SA induced leaves were macerated with citrate-phosphate buffer, $\mathrm{pH} 2.9$, on ice. This solution was then filtered and centrifuged for 30 minutes at $1,000 \mathrm{~g}$, at $4^{\circ} \mathrm{C}$. The supernatant was filtered again and submitted to selfdigestion for 12 hours at $37^{\circ} \mathrm{C}$. New filtration and centrifugation (15 minutes, $1,500 \mathrm{~g})$ were then performed.

After both procedures, the proteins were concentrated with $0.15 \mathrm{mM}$ sodium desoxide-cholate and $10 \%$ trichloroacetic acid (w/v), and separated under denaturing conditions on $10 \%$ slab
polyacrilamide-SDS gels using tris-glycine buffer. Bands were identified by silver staining (SAMMONS et al., 1981).

Plant genomic DNA samples were isolated from fresh leaf tissues, as described by ROY et al. (1992), and used in the polymerase chain reaction (PCR). Three sets of primers (Table 1) were developed based on conserved sequences of various DNA PR protein sequences available on the GenBank (www.ncbi.nlm.nih.gov). The primers were synthesized either at the Polymer Section of Ulm University, Germany, or by a commercial firm (GIBCO-BRL). Each set was designed to identify a group of PR, namely, A: group 3; B: group 1; and C: group 5. The amplification conditions followed the procedures suggested by SAIKI et al. (1988), with a total volume of $20 \mu \mathrm{L}$ : $200 \mathrm{ng}$ of genomic DNA; $0.2 \mu \mathrm{M}$ of each primer; $0.2 \mathrm{mM}$ dNTPs; $1.5 \mathrm{mM}$ of $\mathrm{MgCl}$ buffer; one unit of Taq polymerase. Fragments were amplified in a thermocycler programmed for one cycle of three minutes at $94{ }^{\circ} \mathrm{C}$ followed by 35 cycles of one minute at $94^{\circ} \mathrm{C}$, one minute at $55^{\circ} \mathrm{C}$ (primer $\mathrm{A}$ ) or $47^{\circ} \mathrm{C}$ (primers $\mathrm{B}$ and $\mathrm{C}$ ), one minute at $72{ }^{\circ} \mathrm{C}$, and five minutes of final extension at $72{ }^{\circ} \mathrm{C}$; amplified segments were visualized after separation in $1 \%$ agarose gel. Sequencing of the amplified regions was carried out using the Sanger methodology (SANGER et al., 1977), and commercial USB kits (sequenase PCR product sequencing kit - USB 70700).

\section{RESULTS AND DISCUSSION}

Five major SA-induced proteins with molecular weights of respectively $68,50,45,30$ and 20 $\mathrm{kDa}$ were identified in the intercellular washing fluid (IWF), while two others with molecular weights of 40 and $25 \mathrm{kDa}$ were found in the intracellular extracts only. Negative results were obtained for the controls in respect to these bands. Since the process of extraction and purification used denature completely all the nonPR proteins, a guarantee was obtained that only this type of protein was being considered. All genotypes presented the same induction patterns.

Salicylic acid is one of the best known endogenous regulators of localized and systemic resistance (KLESSIG \& MALAMJ, 1994). Some of the genes activated by this chemical elicitor belong to the PR proteins group (RYALS et al., 1994). In this study no differences were found between the induction patterns of genotypes which are resistant to fungal diseases (BR23, BR32, BR35, TOROPI) and the others.

The DNA fragments obtained from the PCR reactions were sequenced and compared with sequences described in GenBank (Table 1). A search 
Table 1 - Sequences homologous to PR codifying genes obtained for the 14 analyzed genotypes ${ }^{1}$.

1. Primer

3' - GTAGGTGCTCTTGTTCTTCCC

CACATAATTCCCACGAGGATC

Number of amplified base pairs: 400; sequenced: 200

Sequence

acttggaagcagtaccatgtattgtgcgtgacgtgcgeggttggttgetcggcatagacgggaatacagtttagatcgtctacgacgactcattggctcactccaatccattcetgcatcgatc ttccttttggcggctccgegtacacgacagacacgacgtgggetttgacgggtcggtaatcgaagagctttgctccacttgggacagtaccatgtctcattcgtgttgacgttccatgctgata

cagtggaactta

PR group identification: no. 3 - chitinases

2. Primer

3' - CACATTCTCTTCCTCGTGTTC

TAGTTAGCTCCGGTACAAGTG

Number of amplified base pairs: 200; sequenced: 144

Sequence

gttgaaacacgatgttggagagcaggatgatgttcatatgaggactttgatcettttgaggaatttgatcctcgtgggaattatgtgacgacagacacgtctacgagcactcctttacacggg agctcactccaatccattcg

PR group identification: no. 1

\section{Primer}

3' - CGTTGATGCTCGGGGCGCCG

AATTCGCCTCAAGACCTCAC

Number of amplified base pairs: 310; sequenced: 124

Sequence

ttctctttaaca attttttttaccttcttttctcccattttacctgtgatgcctacactcaggacctagtcacaaaaagcactccttttacacgggaccegaacacgaggaagagaatgtg

PR group identification: no. 5 - thaumatin-like

${ }^{1}$ Not underlined: sequences homologous to the indicated PR groups; single underline: site characteristic of PR proteins induced by ethylene; double underline: portion without homology with sequences from the literature.

of the GenBank files showed that, as expected, the first fragment would encode a protein with partial homology to the chitinases (PR3 group, according to LINTHORST, 1991), while the second and third were homologous to the PR1 and PR5 groups, respectively. Again, all genotypes presented the same sequences. Previous reports of PR proteins in wheat, detected with different methods, included PWIR2 (REBMANN et al., 1991; CHEONG et al., 1997); Tal 18 (CRUZ-ORTEGA \& OWNBY, 1993); one chitinase (PR3) and one $\beta$ glucanase (PR2) (DARNETTY et al., 1993); wheatwin1 and wheatwin2 (CARUSO et al., 1996); and TaPR1.1 and TaPR1.2 (MOLINA et al., 1999). Two wheat protein sequences at the Prosite data bank (http:// expasy.hcuge.ch/sprot/sprot-top.html), E13B (PR2) and IAAS (PR6) were also found. It is clear, therefore, that
Triticum aestivum can produce a wide range of PRs. A detailed molecular comparison among them would be most valuable, but complete sequences are required. Variability in host-pathogen interactions can occur at several levels. They include species differences, while diversity within populations may occur due to intraspecific variability, age structure, or social and behavioral differences among hosts or pathogens. Finally, variability within an individual host can arise through genetic differences among pathogens in multiple infections, or through the antigenic variation of a single infection (SCHMID-HEMPEL \& KOELLA, 1994).

In relation to organisms of economic interest, it is always possible that the type of genetic improvement employed for the development of varieties

Ciência Rural, v. 33, n. 3, mai-jun, 2003. 
and races could lead to a disequilibrium in the hostpathogen relationship established during their evolutionary history, leading to the extinction of important defense genes with side effects unfavorable to yield. These genotypes presented average genetic distance of $27 \%$ when random amplified polymorphic DNA markers (RAPD) were used to estimate their genetic variability (FREITAS et al., 2000).

\section{CONCLUSIONS}

Although several PR proteins can be found in wheat, there is uniformity among genotypes in relation to them. As PR proteins have an important role in the defense of crops against pathogens, especially viruses and fungi, the possibility of introducing more variability in this important crop, to obtain enhanced defenses against pathogen attack, should be seriously considered.

\section{ACKNOWLEDGMENTS}

To Ariano Prestes, Maria Irene B. Moraes Fernandes, and Sandra P. Brammer, from EMBRAPA-Centro Nacional de Pesquisa de Trigo, for the provision of material and information; to Suzana Cavalli Molina, Maria Helena B. Zanettini and Mara H. Hutz, of our Department, for laboratory space; and to Programa de Apoio a Núcleos de Excelência (PRONEX), Financiadora de Estudos e Projetos (FINEP), Conselho Nacional de Desenvolvimento Científico e Tecnológico (CNPq), Fundação de Amparo à Pesquisa do Estado do Rio Grande do Sul (FAPERGS), and Pró-reitoria de Pesquisa, Universidade Federal do Rio Grande do Sul (PROPESQ-UFRGS) for research grants.

\section{REFERENCES}

BOL, J.; LINTHORST, H.J.M.; CORNELSSEN, B.J.C. Plantpathogenesis-related proteins induced by virus infection. Annual Review of Phytopathology, Palo Alto, v.28, p.113$138,1990$.

CARUSO, C. et al. Structural and antifungal properties of a pathogenesis-related protein from wheat kernel. Journal of Protein Chemistry, New York, v.15, p.35-44, 1996.

CHEONG, N.E. et al. Purification of an antifungal PR-5 protein from flower buds of Brassica campestris and cloning of its gene. Physiologia Plantarum, Copenhagen, v.101, p.583590, 1997.

CRUZ-ORTEGA, R.; OWNBY, J.D. A protein similar to PR (pathogenesis-related) proteins is elicited by metal toxicity in wheat roots. Physiologia Plantarum, Copenhagen, v.89, p.211-219, 1993.

DARNETTY, et al. Variability in antifungal proteins in the grains of maize, sorghum and wheat. Physiologia Plantarum (Copenhagen), v.88, p.339-349, 1993.
DIXON, R.A.; HARRISON, M.G. Activation, structure and organization of genes involved in microbial defense in plants. Advances in Genetics, San Diego, v.28, p.165-234, 1992.

DURNER, J.; SHAH, J.; KLESSIG, D.F. Salicylic acid and disease resistance in plants. Trends in Plant Science, Oxford, v.2, p.266-274, 1997.

FREITAS, L.B. et al. Extreme homogeneity among Brazilian wheat genotypes determined by RAPD markers. Pesquisa Agropecuária Brasileira, Brasília, v.35, n.11, p.2255-2260, 2000

KLESSIG, D.F.; MALAMJ, J. The salicylic acid signal in plants. Plant Molecular Biology, Dordrecht, v.26, p.14391458, 1994.

LINTHORST, H.J.M. Pathogenesis-related proteins of plants. Critical Reviews in Plant Science, Boca Raton, v.10, p.123150,1991 .

MOHAMED, F.; SEHGAL, O.P. Characteristics of pathogenesis-related proteins induced in Phaseolus vulgaris cv. Pinto following viral infection. Journal of Phytopathology, Berlin, v.45, p.49-58, 1997.

MOLINA, A. et al. Wheat genes encoding two types of PR-1 proteins are pathogen inducible, but do not respond to activators of systemic acquired resistance. Molecular Plant-Microbe Interactions, St. Paul, v.12, p.53-58, 1999.

REBMANN, G.; MAUCH, F.; DUDLER, R. Sequence of a wheat cDNA encoding a pathogen induced thaumatin like protein. Plant Molecular Biology, Dordrecht, v.17, p.283285, 1991.

ROY, A. et al. Segregating random amplified polymorphic DNAs (RAPDs) in Betula alleghaniensis. Theoretical and Applied Genetics, Berlin, v.85, p.173-180, 1992.

RYALS, J.; UKNES, S.; WARD, E. Systemic acquired resistance. Plant Physiology, Rockville, v.104, p.1109-1112, 1994.

SAIKI, R.K. et al. Primer-directed enzymatic amplification of DNA with a thermostable DNA polymerase. Science, Washington, v.239, p.487-491, 1988

SAMMONS, D.W.; ADAMS, L.D.; NISHIZAWA, E.E. Ultrasensitive silver-based color staining of polypeptides in polyacrilamide gels. Electrophoresis, Deerfield Beach, v.2, p. 135-141.1981.

SANGER, F.; NICKLEN, S.; COULSON, A.R. DNA sequencing with chain-terminating inhibitors. Proceedings of the National Academy of Sciences USA, Washington, v.74, p.5463-5467, 1977 .

SCHMID-HEMPEL, P.; KOELLA, J.C. Variability and its implications for host-parasite interactions. Parasitology Today, Oxford, v.10, p.98-102, 1994.

TAMÁS, L.; HUTTOVÁ, J. Accumulation of pathogenesisrelated proteins in barley induced by phosphate and salicylic acid. Biologia, Bratislava, v.51, p.479-484, 1996.

VAN LOON, L.C. Pathogenesis-related proteins. Plant Molecular Biology, Dordrecht, v.4, p.111-116, 1985. 